\title{
PELATIHAN PEMANTAPAN KOMPETENSI GURU DALAM MENGHADAPI UKG (UJI KOMPETENSI GURU)
}

\author{
Nurmalina $^{1}$, Muhammad Hasyimsyah Batubara ${ }^{2}$, Mustafa Kamal Nasution ${ }^{3}$ \\ 1,2,3 IAIN Takengon Aceh Tengah, Aceh, Indonesia \\ email: nurmalina125@gmail.com ${ }^{1}$, muhammad.hasyimsyahbatubara@gmail.com², \\ kamalnasution@gmail.com ${ }^{3}$
}

\begin{abstract}
The rapid progress of science and technology also affects the world of education. In this case, educational resources in schools are teachers, and they must balance science and the use of technology so that the quality of education will remain guaranteed. Because of this, the government held a teacher competency test to evaluate the competencies that teachers musthave. This training aims to strengthen the competencies that teachers must have in preparation for taking the teacher competency test (UKG). The method implemented in this training is the lecture, discussion, and question and answer method with the training participants, namely the SMP Negeri 2 Mesjid Raya teachers. The results of the teacher competency strengthening exercise in facing the teacher competency test are 1) teachers can distinguish activities for each teacher competence, be it professional competence, pedagogic competence, social competence, and personality competence; 2) Teacher competency test motivates teachers to continue to improve the potential contained in each teacher; 3 ) teachers follow the progress of science and technology that is constantly evolving in teaching.; 4) more confident to take the teacher competency test (UKG).
\end{abstract}

Keywords: Teacher competence, Teacher Competency Test (UKG)

\begin{abstract}
Abstrak: Kemajuan ilmu pengetahuan serta tekhnologi yang sedemikian cepat juga mempengaruhi dunia pendidikan. Sumber daya pendidikan yang ada di sekolah dalam hal ini adalah guru, harus ikut menyeimbangkan ilmu pengetahuan dan penggunaan teknologi sehingga mutu pendidikan akan tetap terjamin. Karena hal tersebut pemerintah mengadakan uji kompetensi guru untuk mengevaluasi kompetensi yang harus ada pada para guru. Tujuan dari pelatihan ini ialah untuk memantapkan kompetensi yang harus dimiliki guru sebagai persiapan mengikuti uji kompetensi guru (UKG). Metode yang dilaksanakan pada pelatihan ini ialah metode ceramah, discussion dan tanya jawab dengan peserta pelatihan yaitu guru SMP Negeri 2 Mesjid Raya. Hasil pelatihan pemantapan kompetesi guru dalam menghadapi uji kompetensi guru adalah 1) para guru sudah dapat membedakan kegiatan untuk setiap kompetensi guru, baik itu kompetensi profesional, kompetensi pedagogik, kompetensi social maupun kompetensi kepribadian; 2) uji kompetensi guru memberi motivasi kepada guru untuk terus meningkatkan potensi yang terdapat pada masing-masing diri guru; 3) para guru mengikuti kemajuan ilmu pengetahuan dan juga tekhnologi yang selalu berkembang dalam mengajar; 4) lebih percaya diri untuk mengikuti uji kompetensi guru (UKG) tersebut
\end{abstract}

Kata Kunci: Kompetensi guru, Uji Kompetensi Guru (UKG)

\section{Pendahuluan}

Pendidikan memerlukan guru yang professional dalam bidangnya, supaya lulusan yang dihasilkan dapat mengubah prilaku menjadi pribadi lebih baik serta bertambah ilmu pengetahuan setelah menjalani pendidikan. Sebagaimana disebutkan pada undang-undang pendidikan nomor 20 tahun 2003 tentang sistem pendidikan nasional dalam pasal 1 yang berbunyi "Pendidikan yaitu usaha sadar serta terprogram dalam mewujudkan kondisi belajar dan proses belajar mengajar supaya peserta didik secara aktif meningkatkan potensi dirinya agar mempunyai kemampuan spiritual keagamaan, penguasaan diri, kepribadian, kecerdikan, akhlak mulia, dan keterampilan yang dibutuhkan dirinya, 
masyarakat, bangsa dan negaranya."(Undang-undang Nomor 20 Tahun 2003 Tentang Sistem Pendidikan Nasional). Jadi pelaku pendidikan harus benar-benar memanejemen pendidikan dengan baik, dimulai dari penyediaan sarana dan prasarana pendidikan yang sesuai standar, sumber daya pendidik serta sumber daya kependidikan yang professional, kurikulum dan kebutuhan lain yang mendukung proses pendidikan. Sehingga pendidikan yang diterapkan dapat mengubah para pengenyam pendidikan kearah yang lebih baik.

Pendidikan sangat erat hubungannya dengan tenaga pendidik atau guru. Guru merupakan suatu profesi yang amat mulia serta sangat berperan untuk membantu anakanak bangsa menjadi cerdas. Lebih lanjut Presiden Republik Indonesia mencanangkan guru menjadi sebuah profesi di tanggal 4 Desember 2004, dan memperkukuh peranan guru pada pendidikan dengan mengeluarkan Undang-undang Nomor 14 Tahun 2005 perihal Guru dengan Dosen. Guru dinobatkan menjadi ujung tombak pelaku pendidikan pada sekolah, sebab guru yang berinteraksi langsung dengan peserta didiknya. Melalui gurulah peserta didik belajar langsung akan ilmu pengetahuan dan juga pengembangan karakternya. Sehingga guru yang professional sangat diperlukan di sekolah-sekolah.

Guru yang professional merupakan guru yang ahli dalam bidangnya, bidang yang dimaksud disini adalah bidang pelajaran yang diampunya dan juga kemampuan dalam mengajar. Menurut Zahroh (2015) "guru professional ialah pendidik yang mempunyai kompetensi yang diharuskan untuk melaksanakan tanggung jawab pendidikan serta pengajaran". Kompetensi merupakan keahlian atau kecakapan yang harus dipunyai oleh seseorang pada saat melaksanakan tugas-tugas sesuai pekerjaannya. Pada perihal ini seorang pendidik harus memiliki kompetensi yang berupa pengetahuan, prilaku dan kemampuan professional, baik yang bersifat individu, sosial ataupun kependidikan.

Seorang pendidik profesional harus mempunyai kompetensi-kompetensi yang mendukung profesinya, kompetensi tersebut terdiri dari kompetensi professional, kompetensi pedagogik, kompetensi kepribadian serta kompetensi sosial. Ini sesuai dengan diungkapkan oleh Susanto (2016) yaitu "Kompetensi yang harus dipunyai oleh seorang pendidik professional adalah kompetensi profesional, kompetensi pedagogik, kompetensi kepribadian serta kompetensi sosial.

Uji kompetensi guru dilaksanakan dalam rangka mengukur kompetensi dasar berupa kemampuan dalam menguasai bidang studi dan juga kompetensi pedagogik seorang guru dalam mengajar. Berdasarkan Undang-undang nomor 14 tahun 2005 mengenai guru serta dosen, guru merupakan tenaga profesional. Professional disini ialah suatu tugas yang dilakukan seseorang sebagai sumber pendapatan dalam hidupnya dan membutuhkan keahlian, kepakaran serta kecerdasan dalam memenuhi standar kualitas mutu, aturan tertentu dan membutuhkan pendidikan profesi.

Pelaksanaan uji kompetensi guru ini bertujuan supaya profesionalisme guru dapat terus berkembang seiring perkembangan ilmu pengetahuan, perkembangan zaman, perkembangan teknologi dan kebutuhan stakeholder atau masyarakat. Berdasarkan aturan pelaksanaan uji kompetensi pendidik Pedoman Pelaksanaan Uji Komptensi Guru (2015) menyatakan bahwa "uji kompetensi guru berguna untuk menggambarkan kompetensi pendidik (kompetensi pedagogik dan kompetensi professional), dan selanjutkan menjadi 
dasar program Pengembangan Keprofesian Berkelanjutan (PKB) serta sebagai proses penilaian kinerja dan kompetensi (PKK)". Berdasarkan observasi awal banyak guru yang belum memahami berbagai kompetensi guru yang harus dikuasainya sebagai seorang pendidik, disebabkan banyak guru yang sudah puluhan tahun meninggalkan bangku pendidikannya, menurut paparan di atas betapa pentingnya uji kompetensi guru, maka perlu dilakukan pemantapan materi kompetensi guru sehingga guru-guru diharapkan dapat lebih memahami materi uji kompetensi guru yang diikutinya.

\section{Metode}

Pengabdian ini dilaksanakan di Sekolah Menengah Pertama (SMP) Negeri 2 Mesjid Raya Kecamatan Mesjid Raya Kabupaten Aceh Besar, dengan tujuan meningkatkan kemampuan pendidik dalam memahami kompetensi-kompetensi yang wajib ada pada seorang guru dan persiapan menghadapi Uji Kompetensi Guru. Pelatihan ini dilaksanakan dengan memakai metode ceramah, konsultasi serta tanya jawab pada waktu pemaparan materi kompetensi guru. Untuk memberikan penjelasan dan motivasi digunakan metode ceramah (Sumarni, Prayitno, Anggar, Adiastuty, 2020). Dengan adanya tanya jawab kepada peserta pelatihan maka dapat menggali pengetahuan guru yang tidak dipahami dan tidak diketahui tentang kompetensi yang harus dimilikinya (Santi, Dwi, Setiyani, Asnawati, 2020). Metode ceramah dan tanya jawab dapat membantu peserta pelatihan dalam memahami kompetensi professional dan kompetensi pedagogik yang akan di uji dalam pelaksanaan uji kompetensi guru (UKG). Tahapan pelatihan ini dilaksanakan dengan tahapan pendahuluan, pelaksanaan dan tahap akhir, dapat dilihat pada gambar berikut ini:

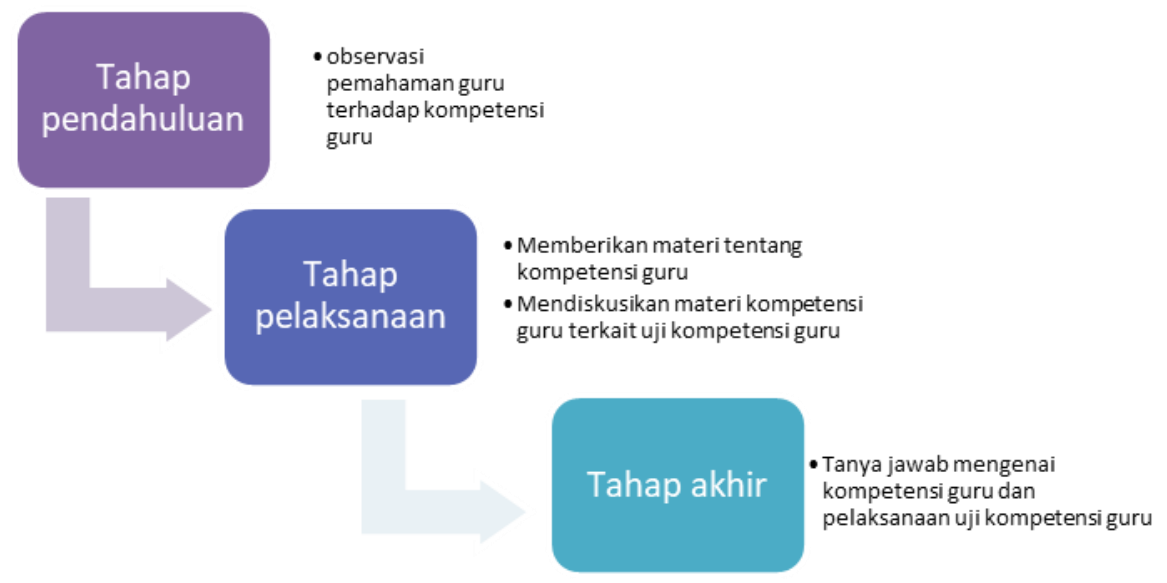

Bagan 1. Alur Pelaksanaan Pengabdian

Tahapan dalam pelatihan kepada guru-guru dilakukan sebagai berikut:

1. Tahap pendahuluan, observasi awal untuk mengetahui pengetahuan awal peserta pelatihan terhadap kompetensi guru yang harus dipahami oleh seorang guru. Selanjutnya melakukan koordinasi untuk menentukan jadwal pelaksanaan pelatihan.

2. Tahap Pelaksanaan, setelah melakukan observasi maka akan dilaksanakan pelatihan pemantapan kompetensi guru. Pada tahap ini peserta pelatihan akan mendapat 
penjelasan mengenai kompetensi yang wajib dimiliki oleh seorang pendidik. terutama kompetensi pedagogik serta kompetensi professional yang termasuk dalam materi uji kompetensi guru, dan juga kompetensi sosial serta kompetensi kepribadian. Pemaparan materi disampaikan pada beberapa sesi pertemuan, dimulai dari sesi penjelasan mengenai kompetensi hingga dengan penjelasan tentang kompetensi yang perlu dipahami oleh seorang guru professional serta kegunaan uji kompetensi guru.

3. Tahap akhir, pada tahap ini pemateri dan peserta berdiskusi dan tanya jawab mengenai materi kompetensi guru dan uji kompetensi guru. Tanya jawab tersebut dapat memberi gambaran tentang materi yang belum dipahami jelas oleh peserta pelatihan.

\section{Hasil dan Pembahasan}

Sumber daya manusia yang sangat mempengaruhi mutu pendidikan adalah guru, karena itu guru perlu pembinaan secara kontinue. Mutu pendidikan perlu dilakukan pengendalian supaya tidak jauh menyimpang dari tujuan utama pendidikan. Tujuan pengedalian mutu menurut Rohmah, Noer, Fanani (2017) yaitu melaksanakan penilaian dan perbaikan supaya apa yang sudah direncanakan dapat tercapai secara maksimal.

Pelatihan pemantapan kompetensi guru dalam menghadapi UKG (Uji Kompetensi Guru) dilaksanakan pada Sekolah Menengah Pertama (SMP) Negeri 2 Mesjid Raya Kecamata Mesjid Raya Kabupaten Aceh Besar yang diikuti 28 orang guru. Menurut Nurbaiti (2019) "Uji kompetensi guru (UKG) ialah suatu kegiatan uji yang dilaksanakan guna mengukur kemampuan dasar terkait bidang studi yang diajarkan serta kompetensi pedagogik". Bagi pendidik yang sudah sertifikasi maka kompetensi dasar mata pelajaran yang diuji sama dengan bidang studi sertifikasinya, sedangkan untuk pendidik yang belum mempunyai sertifikasi maka sesuai kepada kualifikasi akademiknya.

Uji kompetensi guru diikuti oleh semua guru yang sudah mempunyai Nomor Unik Pendidik serta Tenaga Kependidikan (NUPTK) baik yang telah memiliki sertifikat pendidik atau belum memiliki sertifikat pendidik, sebagaimana persyaratan peseta Uji Kompetensi Guru yang terdapat pada pedoman pelaksanaan Uji kompetensi Pedoman Pelaksanaan Uji Komptensi Guru (2015) yaitu:

1. Seluruh guru yang telah memiliki sertifikat pendidik dan yang belum memiliki sertifikat pendidik

2. Semua pendidik yang telah terdaftar pada Data Pokok Pendidikan (Dapodik) baik berkedudukan sebagai guru PNS ataupun guru yang belum PNS.

3. Mempunyai NUPTK (Nomor Unik Pendidik dan Tenaga Kependidikan) atau Peg.Id.

4. Mengajarkan mata pelajaran sesuai bidang studi sertifikasi serta sesuai kualifikasi akademik dan masih aktif.

Kompetensi ialah kemampuan yang perlu dimiliki oleh guru. Menurut Mulyasa (2007) kompetensi ialah perpaduan antara knowledge, keterampilan, value serta sikap yang dispekulasikan pada kebiasaan berfikir, serta bertindak. Sedangkan berdasarkan Kunandar (2007) kompetensi adalah kesatuan cerdas, penuh pertanggung jawaban yang dipunyai seseorang untuk syarat guna dianggap sanggup oleh masyarakat untuk melakukan tugas-tugas dalam bagian pekerjaan tertentu. Jadi kompetensi ialah suatu 
keahlian atau keterampilan yang menjadi tanggung jawab seseorang dalam menjalankan tugasnya. Begitu juga dengan seorang guru perlu mempunyai kompetensi untuk menjalankan tugasnya. Sebagaimana yang disbutkan oleh Majid (2005) kompetensi yang harus dipunyai setiap pendidik dapat memperlihatkan kualitas guru pada saat proses belajar mengajar.

Kompetensi pada UU No. 14 tahun 2005 mengenai Guru serta Dosen menjelaskan bahwa kompetensi ialah seperangkat ilmu pengetahuan, keahlian, dan sikap yang perlu dimiliki, dirasakan, dan dipahami oleh pendidik dalam melakukan tugas profesinya. Kompetensi ini meliputi (1) Kompetensi pedagogic; (2) Kompetensi professional; (3) Kompetensi social; (4) Kompetensi kepribadian. Kemudian dijelaskan sebagaimana berikut:

\section{Kompetensi pedagogic}

Kompetensi pedagogic pada dasarnya ialah keahlian yang perlu dimiliki pendidik dalam memberikan materi tertentu kepada siswanya pada saat proses belajar mengajar, meliputi :

a. Mengetahui karakteristik siswa dari berbagai segi, social, akhlak, budaya, emotional, dan juga intelektual;

b. Mengetahui gaya belajar serta kesulitan belajar siswa;

c. Menyediakan pengembangan potensi siswa;

d. Memahami teori dan asas belajar serta proses belajar yang mendidik;

e. Meningkatkan kurikulum yang mendukung keterlibatan siswa dalam pembelajaran;

f. Menyusun pembelajaran yang mengedukasi;

g. Melakukan pembelajaran yang mengedukasi;

h. Memahami background keluarga dan masyarakat siswa serta keerluan belajar pada konteks keaneka ragaman budaya;

i. Menilai proses serta hasil pembelajaran.

Menurut Mulyasa kompetensi pedagogic ialah kemampuan mengatur pembelajaran siswa yang terdiri dari pemahaman untuk peserta didik, penyusunan serta pelaksanaan pembelajaran, penilaian hasil belajar, dan peningkatan peserta didik dalam mengaktualisasikan beragam potensi yang ada padanya (Mulyasa, 2009). Jadi kompetensi pedagogic ialah kesanggupan dalam menata pembelajaran yang mengedukasi.

2. Kompetensi professional

Yaitu kemampuan dalam menguasai materi pembelajaran sepenuhnya dan mendalam sehingga dapat membimbing siswa memenuhi dasar kompetensi. Menurut Samani kompetensi profesional ialah keahlian penguasaan materi pembelajaran secara baik sehingga guru dapat membimbing siswa mencukupi standar kompetensi yang telah ditetapkan pada standar nasional pendidikan (Samani, 2010).

Diharapkan guru dapat memahami makna inti bidang studi serta metodologi keilmuannya, memahami struktur dan materi kurikulum mata pelajarannya, mengelompokkan materi kurikulum mata pelajarannya, menguasai dan menggunakan teknologi informasi serta komunikasi pada pembelajaran, mengembangkan kualitas pembelajaran melalui penilaian dan penelitian. 


\section{Kompetensi social}

Merupakan kemampuan pendidik untuk berkomunikasi secara efektif dengan para siswa, sesama guru, dengan tenaga kependidikan, para orang tua/wali, serta masyarakat. Sebagaimana yang diungkapkan Uno (2008) kompetensi sosial ialah guru harus memperlihatkan atau dapat berinteraksi sosial, baik dengan peserta didiknya ataupun dengan sesama pendidik serta kepala sekolah, bahkan pada masyarakat luas. Dengan demikian guru diharapkan mampu berkomunikasi dengan simpatik serta empatik pada peserta didik, orang tua/wali peserta didik, sesama sumber daya pendidik dan sumber daya kependidikan, serta masyarakat, dan memiliki kontribusi terhadap pertumbuhan siswa, sekolah serta masyarakat, dan bisa menggunakan teknologi informasi serta komunikasi (ICT) dalam berkomunikasi serta pengembangan diri.

4. Kompetensi kepribadian

Kepribadian yang baik, stabil, dewasa, arif bijaksana serta berwibawa harus dimiliki oleh seorang pendidik agar menjadi teladan untuk peserta didik serta masyarakat, dan berakhlak mulia; supaya menjadi teladan untuk peserta didik serta masyarakat; dan dapat mengevaluasi kinerja masing-masing (tindakan reflektif) dan dapat mengembangkan diri dengan kontinue. Menurut Mulyasa (2009) pribadi pendidik mempunyai andil yang amat besar dalam keberhasilan pendidikan, khususnya pada kegiatan pembelajaran. Kompetensi kepribadian amat besar pengaruhnya kepada pertumbuhan serta perkembangan pribadi para siswa.

Pada saat observasi awal kebanyakan guru pada sekolah tersebut belum memahami tentang kompetensi guru secara teori, tetapi pada prakteknya, mereka sudah menjalankan dengan baik. Pada pelaksanaan pelatihan pemantapan kompetensi guru materi disampaikan dengan jelas kepada peserta pelatihan. Kemudian dilanjutkan dengan tanya jawab mengenai kompetensi yang akan diuji dalam uji kompetensi guru (UKG).

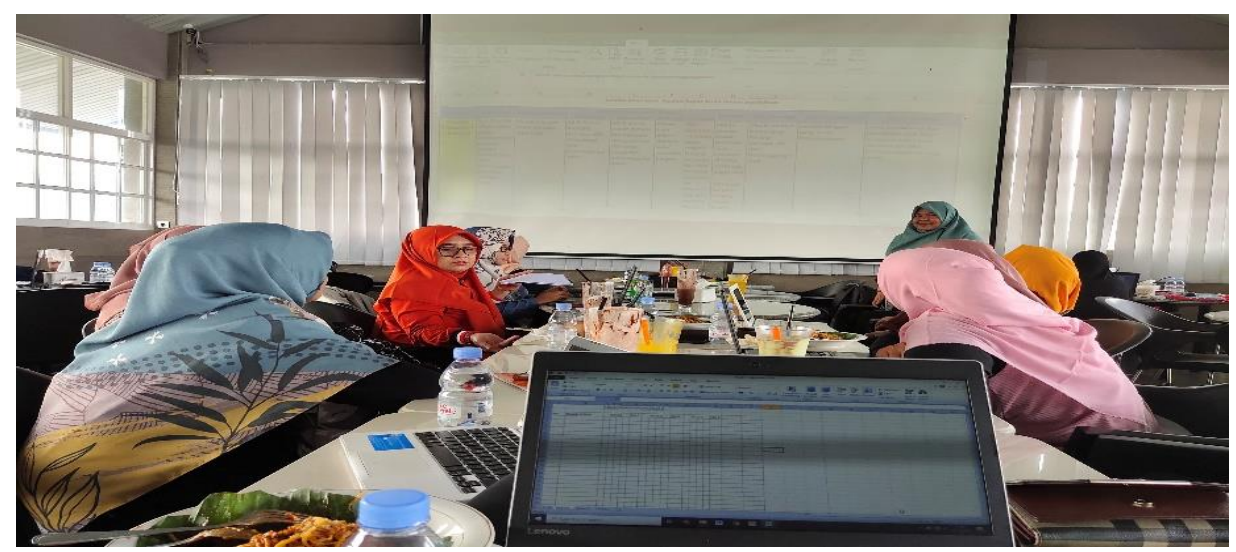

Gambar 1. Suasana pelatihan pemantapan kompetensi guru pada saat diskusi dan Tanya jawab.

Pelaksanaan uji kompetensi guru dapat memotivasi guru untuk mengembangkan dirinya baik dalam segi ilmu pengetahuan, penguasaan materi maupun perkembangan tekhnologi. Munculnya motivasi dalam diri seseorang guru karena adanya dorongan dari pimpinannya sebagaimana yang diungkapkan oleh Saefullah (2014) "dalam meningkatkan motivasi guru diperlukan pengkodisian oleh pimpinan terutama untuk 
meningkatkan kinerja guru". Uji kompetensi guru (UKG) diselenggarakan pemerintah untuk meningkatkan kinerja guru agar menjadi guru yang berkualitas. Sehingga hasil dari uji kompetensi guru bisa untuk pemetaan guru.

Namun perlu tindak lanjut dari pemerintah sebagai upaya untuk selalu meningkatkan kualitas guru sehingga dapat mengikuti perkembangan zaman. Wardhani (2017) mengatakan mengadakan diklat sesuai dengan yang dibutuhkan guru dalam meningkatkan profesionalismenya sebagai salah satu bentuk upaya tindak lanjut dari pemerintah. Jadi diadakan pelatihan pemantapan kompetensi guru ini untuk meningkatkan motivasi guru dalam meningkatkan profesionalismenya. Guru-guru lebih semangat dalam memahami kompetensi guru dan belajar kembali materi pelajaran yang sesuai dengan bidang studi sertifikasinya. UKG (Uji Kompetensi Guru) bertujuan untuk tetap menjaga kompetensi pendidik (kompetensi pedagogic dan juga kompetensi professional) supaya kualitas pendidikan dapat meningkat (Arafah Bahruddin, Siti, In'am, Ahsanul, Lendriyono, 2019).

Berdasarkan hasil pembahasan dan tanya jawab bersama peserta pelatihan, para guru bisa memahami dan memilih dan memilah kegiatan yang mereka lakukan selama ini termasuk kepada kompetensi apa saja. Misalnya penguasaan materi termasuk dalam kompetensi professional, cara mengajar termasuk dalam kompetensi pedagogik.

\section{Kesimpulan}

Pada dasarnnya guru sudah menjalankan apa yang dinyatakan dalam 4 (empat) kompetensi yang wajib dimiliki oleh guru berdasarkan Undang-Undang Nomor 14 Tahun 2005 terkait guru dan juga dosen. Akan tetapi belum memahami secara jelas kegiatankegiatan di dalam ke empat kompetensi tersebut. Dalam pelaksanaan UKG (Uji Kompetensi Guru), materi yang akan di uji terkait kompetensi pedagogik dan juga kompetensi professional. Sehingga untuk pemantapan kompetensi guru untuk menghadapi UKG (Uji Kompetensi Guru) diadakan pelatihan yang diikuti oleh semua pendidik pada Sekolah Menengah Pertama (SMP) Negeri 2 Mesjid Raya, baik yang telah mempunyai sertifikat pendidik ataupun yang belum mempunyai sertifikat pendidik. Karena UKG (Uji Kompetensi Guru) ini bertujuan untuk menjadikan guru lebih berkualitas dan professional di bidang studi masing-masing. Setelah pelatihan ini para guru sudah lebih dapat memahami yang mana kompetensi professional, kompetensi pedagogic, kompetensi social serta kompetensi kepribadian yang dibuktikan dengan diskusi dan tanya jawab pada tahap akhir pelatihan ini..

\section{Ucapan Terima Kasih}

Ungkapan rasa terima kasih yang tak terhingga penulis ucapkan untuk kepala sekolah serta para guru Sekolah Menengah Pertama (SMP) Negeri 2 Mesjid Raya Kecamatan Mesjid Raya, Kabupaten Aceh Besar yang telah memberi kesempatan kepada penulis untuk melaksanakan pengabdian ini. 
Jurnal Pengabdian Masyarakat As-Salam (JPMA)

Vol. 1 No. 1 Januari - Juni 2021: 16 - 23

Nurmalina, Muhammad Hasyimsyah Batubara, Mustafa Kamal Nasution

\section{Daftar Pustaka}

Bahruddin, S. A., In'am, A., \& Lendriyono, F. (2020). Analisis Hasil Uji Kompetensi Guru Tahun 2015 Di Provinsi Nusa Tenggara Timur. Jurnal Kebijakan Dan Pengembangan Pendidikan, 7(1). https://doi.org/10.22219/jkpp.v7i1.12038.

Kunandar. (2007). Guru Profesional: Implementasi Kurikulum Tingkat Satuan Pendidikan dan sukses dalam sertifikasi. Depok: RajaGrafindo Persada.

Majid, A. (2005). Perencanaan Pembelajaran: Mengembangkan Standar Kompetensi Guru. Bandung: Remaja Rosdakarya.

Mulyasa, E. (2007). Menjadi Guru Professional Menciptakan Pembelajaran Kreatif dan Menyenangkan. Bandung: Remaja Rosdakarya.

Mulyasa, E. (2009). Standar Kompetensi dan Sertifikasi Guru. Bandung: Remaja Rosdakarya.

Nurbaiti. (2019). Implementasi Kebijakan Uji Kompetensi Guru (UKG) Dinas Pendidikan Pemuda dan Olahraga Kota Palembang. Prosiding Seminar Nasional Pendidikan Program Pascasarjana Universitas Pgri Palembang 12 Januari 2019. 650-663.

https://jurnal.univpgri-

palembang.ac.id/index.php/Prosidingpps/article/view/2606/2421

Peraturan Menteri Pendidikan Dan Kebudayaan Republik Indonesia Nomor 43 Tahun 2015 Tentang Uji Kompetensi Guru Atau Pendidik Lainnya Dan Tenaga Kependidikan.

Rohmah, Noer, Fanani, Z. (2017). Pengantar Manajemen Pendidikan. Malang: Madani.

Saefullah. (2014). Manajemen Pendidikan Islam. Bandung: Pustaka Setia.

Samani. (2010). Mengenal Sertifikasi Guru di Indonesia. SIC dan Asosias iPeneliti Pendidikan Indonesia (APPI).

Santi, Dina Pratiwi Dwi, Setiyani, Asnawati, S. (2020). Pemberdayaan Orang Tua Siswa TK Annur Kabupaten Cirebon Melalui Keterampilan Rajut Tangan dan Access Market. Al Khidmat, 3(2). 42-50.

file://C:/Users/ASUS/Downloads/9558-31678-1-PB.pdf

Sumarni, Sumarni, Tiyas Prayitno, Anggar, Adiastuty, N. (2020). Pendampingan Penulisan Artikel Ilmiah Bagi Guru-Guru Sma Kecamatan Jalaksana Kabupaten Kuningan. AL KHIDMAT, 3(1). 15-24.

file:///C:/Users/ASUS/Downloads/6243-25641-1-PB.pdf

Undang-undang Nomor 20 Tahun 2003 Tentang Sistem Pendidikan Nasional. http://pendis.kemenag.go.id/file/dokumen/uuno20th2003ttgsisdiknas.pdf

Uno, H. (2008). Profesi Kependidikan Problema, Solusi, dan Reformasi Pendidikan di Indonesia. Jakarta: Bumi Aksara.

Wardhani, F. R. (2017). Analisis Kompetensi Guru Berbasis Uji Kompetensi Guru (UKG) Pada Guru Sekolah Menengah Kejuruan (SMK) Bidang Keahlian Administrasi Perkantoran Di Surakarta Tahun Ajaran 2015/2016. Jurnal Informasi Dan Komunikasi Administrasi Perkantoran, 1(1). 75-84. https://jurnal.uns.ac.id/JIKAP/article/view/19550

Zahroh, A. (2015). Membangun Kualitas Pembelajaran Melalui Dimensi Profesional Guru. Bandung: Yrama Widya. 